\title{
The relative labour productivity contribution of different age-skill categories for a developing economy
}

\author{
Author: \\ Gerhardus van Zyl ${ }^{1}$ \\ Affiliation: \\ ${ }^{1}$ Department of Economics \\ and Econometrics, University \\ of Johannesburg, \\ South Africa \\ Correspondence to: \\ Gerhardus van Zyl \\ Email: \\ hardusvz@uj.ac.za \\ Postal address: \\ PO Box 10152, Aston Manor \\ 1630 , South Africa \\ Dates: \\ Received: 10 Apr. 2012 \\ Accepted: 27 Aug. 2012 \\ Published: 31 Jan. 2013 \\ How to cite this article: \\ Van Zyl, G. (2013). The \\ relative labour productivity \\ contribution of different \\ age-skill categories for a \\ developing economy. SA \\ Journal of Human Resource \\ Management/SA Tydskrif vir \\ Menslikehulpbronbestuur, \\ 11(1), Art. \#472, 8 pages. \\ http://dx.doi.org/10.4102/ \\ sajhrm.v11i1.472

\section{Copyright:} \\ (C) 2013. The Authors. \\ Licensee: AOSIS \\ OpenJournals. This work \\ is licensed under the \\ Creative Commons \\ Attribution License.
}

Read online:
Orientation: The article dealt with the estimation, computation and interpretation of the relative productivity contributions of different age-skill categories.

Research purpose: The aim of the article was to estimate and compute, (1) relative productivity contributions and (2) relative productivity contribution-employee remuneration cost levels for different age-skill categories.

Motivation for the study: The research was deemed necessary given the current debate on relative productivity levels and possible changes to the retirement age in the South African labour market. No real research in this regard has been published regarding the South African labour market situation.

Research design, approach and method: A less restrictive production function was used, allowing for the simultaneous estimation and final computation of relative labour contribution levels of different age-skill categories.

Main findings: The lower-skilled segment produced significantly smaller productivity contributions and the relative productivity contribution-employee remuneration cost ratios of the 55 years and older age group were superior in the higher-skilled segment but, at the same time, the lowest in the lower-skilled segment.

Practical/managerial implications: It is recommended that human resource practitioners (given the perceived rigidity of labour legislation) implement and maintain structures that promote higher productivity levels for all age-skill categories in the workplace.

Contribution/value-add: An estimation procedure, which can be applied to the measurement of the relative productivity contribution of different age-skill categories, has been established.

\section{Introduction}

\section{Problem statement}

The article adds new insight into the age-real productivity debate in South Africa, as no estimation, computation, quantification and interpretation of this magnitude on the age-relative labour productivity and employee remuneration cost ratios (when different skill levels are taken into consideration) has previously been conducted. The manufacturing, construction and the trade and accommodation industries of the Gauteng Province of South Africa are used as case studies. There is a general debate on, (1) relative productivity levels and (2) the retirement age in the South African economy and the possible impact (if any) that a change in the retirement age might have on labour productivity benefits, the potential loss of valuable expertise and the possible creation of a further loss of skilled employees. This particular research focuses on the age-real productivity aspect of this debate.

Over the past two decades, renewed research interest has focused on the relationship between the different employee age groups and labour productivity in the workplace. The increasing ageing profile of populations in developed economies (especially in Europe) and its impact on those economies has prompted more research (Colonia-Willner, 1998; Daveri \& Maliranta, 2006; Dostie, 2006; Guest \& Shacklock, 2005; Malmberg, Lindh \& Halvarsson, 2005; Remery, Henkins, Schippers \& Ekamper, 2003; Roger \& Wasmer, 2009; Skirbekk, 2003; Vandenberghe \& Waltenberg, 2010) on the age-productivity relationship. No real research has been conducted in this regard for developing economies, where the realities are (1) real positive population growth rates, (2) a greater number of younger people entering the job market and (3) a growing component of active employees at the higher end of the age groups.

\section{Literature review}

Daveri and Maliranta (2006), Guest and Shacklock (2005), Remery et al. (2003) and Van Ours and Stoeldraijer (2010) indicated very low and even negative productivity differentials for 
older employees. These studies concluded that, (1) lower productivity differentials for older employees are caused by higher employee remuneration costs and, at the same time, an inability to adapt to new technology and structural changes in the labour market, (2) a general preference exists for younger employees (simply as a result of relative lower employee remuneration costs), (3) greater discrepancies exist between the productivity contribution levels of 'older' employees and remuneration levels (the argument is that marginal productivity levels are growing slower than employee remuneration levels) and (4) firms tend to follow rigid employee remuneration schemes (based on qualifications, experience and tenure) and would then be inclined to adjust their employment structures and not necessarily nominal employee remuneration levels. ColoniaWillner (1998), Dostie (2006), Roger and Wasmer (2009) and Vandenberghe and Waltenberg (2010) concluded that, in certain circumstances, the real productivity contribution levels for 'older' employees can be significantly positive because of certain job categories requiring a longer timeframe for the accumulation of job-specific skills and experience. The Roger and Wasmer (2009) study specifically indicated that older, higher-skilled employees were the most productive, whilst older, lower-skilled employees were the least productive when compared to the other age groups.

General aspects on the age-labour productivity relationship, for which all the abovementioned studies are in agreement, are that:

- Employee remuneration differentials reflect actual differences in relative productivity contribution levels for the different age groups.

- Employee remuneration levels tend to vary far less than relative productivity levels.

- A definite inequality exists between relative productivity contributions and employee remuneration levels for all the different age groups (the argument is that employee remuneration differentials do reflect actual differences in employee productivity).

- Relative productivity contribution-levels tend to reach a maximum and then decline as employees become older.

- Employers are constantly trying to achieve an employeeage mix that would yield the highest possible relative productivity contribution levels.

In terms of the measurement of the productivity contribution of the different age-skill categories, the majority of the studies (Daveri \& Maliranta, 2006; Dostie, 2006; Guest \& Shacklock, 2005; Vandenberghe \& Waltenberg, 2010) used a restrictive production function methodology. A less restrictive measurement methodology was developed by Roger and Wasmer (2009) in their extensive study on the actual profile of relative productivity contributions across the different age groups in the manufacturing, services and trade sectors of the French economy. These authors developed a unique and less restrictive production function in which the labour input was treated as a nested constant elasticity substitution (CES) model. In this particular model, (1) a smaller number of constraints were imposed on production technology and (2) the imperfect substitution between the different categories of employees was allowed for. The model also, (1) enabled the differentiation of employees simultaneously by age and skill level and (2) estimated the differences in the ageproductivity and age-employee remuneration (in relative terms) separately within each skill level.

\section{Research design Research approach and method}

The research design comprises the, (1) specification of an econometric model that would capture the relative labour productivity contributions for the different age groups (in accordance with the different skill levels), (2) identification of the different industries that would serve as proxies for the estimation and computation of the different relative productivity contribution and relative productivity contribution-employee remuneration ratios, (3) statistical validation of the required sample of businesses and the data collected in the proxy industries and (4) estimation and computation process and the interpretation of the estimation and computation results.

\section{Measuring instrument}

A simplified version of the Roger and Wasmer (2009) model was used for this particular research. The International Standard Classification of Occupations (ISCO-88) was used for the differentiation of the different skill levels. Category A constituted the more skilled employee segment, whilst Category B constituted the less skilled employee segment. In terms of the different age groups, three categories were identified, namely employees aged, (1) 35 years and younger, (2) older than 35 years but younger than 55 years and (3) 55 years and older. These age categories were specifically chosen in order to allow for comparative analysis with similar research results. In terms of the estimation and computation process, the different employee categories were treated heterogeneously across the defined age-skill groups, but homogeneously within the different age-skill groups. This simply means that employees belonging to the same age-skill group were assumed to be perfectly substitutable.

The methodology of the model of Roger and Wasmer (2009, pp. 10-12, 19, 27-35), as applied in this particular study, was explained in the following few paragraphs. In the model, the aggregate labour input (high-skilled and low-skilled employees) took the form of a nested CES function:

$\mathrm{L}=\left(\Sigma \delta_{\mathrm{i}} \mathrm{L}_{\mathrm{i}}^{\mathrm{pi}}\right)^{1 / \mathrm{p}_{\mathrm{i}}}$

[Eqn 1]

where $\mathrm{L}=$ labour, $\mathrm{i}=$ skill category, $\delta_{\mathrm{i}}=$ distribution parameter and $\mathrm{p}_{\mathrm{i}}=$ substitution parameter.

In terms of the different age-skill categories, each skill category was treated as a CES function by itself:

$\mathrm{L}_{\mathrm{i}}=\left(\sum_{\mathrm{i}} \delta_{\mathrm{ij}} \mathrm{L}_{\mathrm{ij}} \mathrm{pij}^{1 / \mathrm{p}_{\mathrm{ij}}}\right.$

[Eqn 2] 
where $\mathrm{i}=$ skill category, $\mathrm{j}=$ age category, $\delta_{\mathrm{ij}}=$ distribution parameter per age-skill category and $\mathrm{p}_{\mathrm{ij}}=$ substitution parameter per age-skill category.

In the estimation process, the distribution- as well as the substitution parameters were estimated, followed by the estimation of the productivity differentials per age-skill category. In order to estimate the productivity contribution per employee category the marginal productivity (MP) for each employee category was computed (given the estimated values of the CES parameters). It is important to note that, (1) constant returns to scale was assumed and (2) that the Euler's theorem was used in order to specify the labour function. This particular function is homogeneous to the degree of 1 and was presented as a sum of labour inputs times the marginal productivities:

$\left.\mathrm{f}\left(\mathrm{L}, \mathrm{L}_{2} \ldots \ldots \mathrm{L}_{\mathrm{n}}\right)=\mathrm{L}_{1} \partial \mathrm{f} / \partial \mathrm{L}_{1}+\mathrm{L}_{2} \partial \mathrm{f} / \partial \mathrm{L}_{2}+\ldots \mathrm{L}_{\mathrm{n}} \partial \mathrm{f} / \partial \mathrm{L}_{\mathrm{n}}\right)$

[Eqn 3]

where $\mathrm{f}=$ the function of labour, $\mathrm{L}_{1} \mathrm{~L}_{2} \mathrm{~L}_{\mathrm{n}}=$ labour inputs and $\partial / \mathrm{L}=$ marginal productivity per labour input.

In order to cater for skill differentiation the marginal product for each skill category was computed:

$\mathrm{MP}_{\mathrm{i}}=\partial \mathrm{Y} / \partial \mathrm{L} \cdot \partial \mathrm{L} / \partial \mathrm{L}_{\mathrm{i}}$

[Eqn 4]

where $\mathrm{Y}=$ output, $\mathrm{L}=$ labour input and $\mathrm{L}_{\mathrm{i}}=$ different skill levels.

In terms of the nested CES function, the marginal productivity per skill category was presented as:

$\mathrm{MP}_{\mathrm{i}}=\mathrm{AK}{ }^{\alpha} \beta\left(\sum_{\mathrm{i}} \delta_{\mathrm{i}} \mathrm{L}_{\mathrm{i}}^{\mathrm{pi}}\right)^{\beta / \mathrm{pi}-1} \delta_{\mathrm{i}} \mathrm{L}_{\mathrm{i}}^{\mathrm{p}-1}$

where $\mathrm{MP}_{\mathrm{i}}=$ marginal productivity per skill category, $\mathrm{K}=$ capital input, $\alpha=$ marginal productivity of capital, $\delta_{\mathrm{i}}=$ distribution per skill category, $\mathrm{L}_{\mathrm{i}}=$ employee skill category and $\mathrm{p}_{\mathrm{i}}=$ substitution parameter per skill category.

The ratio of the different skill levels was computed in order to determine the relative marginal productivity for the different employee skill categories:

$\mathrm{MP}_{1} / \mathrm{MP}_{2}=\partial \mathrm{L} / \partial \mathrm{L}_{1} \div \partial \mathrm{L} / \partial \mathrm{L}_{2}=\lambda=\delta_{1} / \delta_{2}\left(\mathrm{~L}_{1} / \mathrm{L}_{2}\right)^{\mathrm{pi}-1} \quad$ [Eqn 6]

where $\lambda=$ ratio of the marginal productivities of the two skill categories 1 and 2 and $\delta_{1} / \delta_{2}=$ ratio of the distribution parameters for skill categories 1 and 2 .

A comparison of productivity contributions over different skill categories requires the estimation of the ratio between the marginal productivity of a skill category and the average marginal productivity of the total labour input:

$\mathrm{MP}_{1} / \mathrm{MP}_{\mathrm{av}}=\mathrm{L} / \mathrm{L}_{1}+\lambda^{-1} \mathrm{~L}_{2}$ and $\mathrm{MP}_{2} / \mathrm{MP}_{\mathrm{av}}=\mathrm{L} / \lambda \mathrm{L}_{1}+\mathrm{L}_{2} \quad$ [Eqn 7]

where $\mathrm{MP}_{\mathrm{av}}$ = average marginal productivity for the total labour input.
In terms of the impact of age differentiation on labour productivity, the marginal productivity per age-skill category is computed:

$\mathrm{MP}_{\mathrm{ij}}=\partial \mathrm{Y} / \partial \mathrm{L} \cdot \partial \mathrm{L} / \partial \mathrm{L}_{\mathrm{i}} \cdot \partial \mathrm{L}_{\mathrm{i}} / \partial \mathrm{L}_{\mathrm{ij}}$

[Eqn 8]

where $\mathrm{MP}_{\mathrm{ij}}=$ marginal productivity per age-skill category.

and

$\mathrm{MP}_{\mathrm{i}}=\mathrm{AK}^{\alpha} \beta\left(\Sigma \delta_{\mathrm{i}} \mathrm{L}_{\mathrm{i}}^{\mathrm{pi}}\right)^{\beta / \mathrm{pi}-1} \delta_{\mathrm{i}} \mathrm{Li}^{\mathrm{pi} / \mathrm{pj}-1} \delta_{\mathrm{ij}} \mathrm{L}_{\mathrm{ij}}^{\mathrm{pij}-1}$

[Eqn 9]

where $\delta_{\mathrm{ij}}=$ distribution parameter per age-skill category and $\mathrm{p}_{\mathrm{ij}}=$ substitution parameter per age-skill category.

The relative marginal productivity of any two age groups of employees in a given skill category is:

$\mathrm{MP}_{\mathrm{i} 1} / \mathrm{MP}_{\mathrm{i} 2}=\delta_{\mathrm{i} 1} / \delta_{\mathrm{i} 2}\left(\mathrm{~L}_{\mathrm{i} 1} / \mathrm{L}_{\mathrm{i} 2}\right)^{\mathrm{pij}-1}$

[Eqn 10]

The relative marginal productivities between the different age categories were:

- Relative marginal productivity for employees younger than 35 years versus employees older than 35 years but younger than 55 years of age, represented as:

$\mathrm{MP}_{\mathrm{i} 35<} / \mathrm{MP}_{\mathrm{i} 35-55}=\varphi$

[Eqn 11]

- Relative marginal productivity for employees younger than 35 years versus employees 55 years and older, represented as:

$\mathrm{MP}_{\mathrm{i} 35<} / \mathrm{MP}_{\mathrm{i} 55+}=\gamma$

- Relative productivity for employees older than 35 years but younger than 55 years versus employees 55 years and older, represented as:

$\mathrm{MP}_{\mathrm{i} 35-55} / \mathrm{MP}_{\mathrm{i} 55+}=\eta$

[Eqn 13]

The productivity contribution of each age category was then given by the ratio of the marginal productivities of the respective age group over the average marginal productivity of a specific skill category:

$\mathrm{MP}_{\mathrm{i} 35<} / \mathrm{MP}_{\mathrm{av}}=\mathrm{L}_{\mathrm{i}} / \mathrm{L}_{\mathrm{i} 35<}+\varphi^{-1} \mathrm{~L}_{\mathrm{i} 35-55}+\gamma^{-1} \mathrm{~L}_{\mathrm{i} 55+}$

$\mathrm{MP}_{\mathrm{i} 35-55} / \mathrm{MP}_{\mathrm{av}}=\mathrm{L}_{\mathrm{i}} / \varphi \mathrm{L}_{\mathrm{i} 35<}+\mathrm{L}_{\mathrm{i} 35-55}+\eta^{-1} \mathrm{~L}_{\mathrm{i} 55+}$

$\mathrm{MP}_{\mathrm{i} 55+} / \mathrm{MP}_{\mathrm{av}}=\mathrm{L}_{\mathrm{i}} / \gamma \mathrm{L}_{\mathrm{i} 35<}+\eta \mathrm{L}_{\mathrm{i} 35-55}+\mathrm{L}_{\mathrm{i} 55+}$

In order to estimate the distribution and substitution parameters that are necessary to determine the productivity contributions of the different age-skill categories, the production function model (in which labour is differentiated simultaneously by the different age and skill categories) was estimated as:

$\mathrm{Y}=\mathrm{AK}^{\alpha}\left(\gamma\left(\delta_{\mathrm{L} 35<} \mathrm{L}_{135<}{ }^{\mathrm{pl}}+\delta_{135-55} \mathrm{~L}_{35-551^{\mathrm{pl}}}+\left(1-\delta_{135<}-\delta_{\mathrm{lm}}\right) \mathrm{L}_{\mathrm{lo}}{ }^{\mathrm{pl}}\right)\right.$

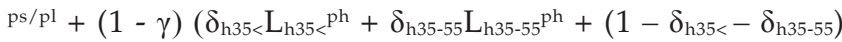
$\left.\left.\mathrm{L}_{\mathrm{h} 55+}{ }^{\mathrm{ph}}\right)^{\mathrm{ps} / \mathrm{ph}}\right)^{\beta / \mathrm{ps}}$

[Eqn 17]

where $\gamma=$ the ratio of the marginal productivities of the 35-55 years and the 55 years and older age groups, 
$\delta_{\mathrm{LY}}=$ distribution parameter of the lower skill 35 years and younger age category, $\delta_{\mathrm{Lm}}=$ distribution parameter of the lower skill 35-55 years age category, $\delta_{\text {hy }}=$ distribution parameter of the higher skill 35 years and younger age category, $\delta_{\mathrm{hm}}=$ distribution parameter of the higher skill $35-55$ years age category, $\mathrm{L}_{135<}{ }^{\mathrm{pl}}=$ substitution parameter of the lower skill 35 years and younger age category, $\mathrm{L}_{135-551^{\mathrm{pl}}}$ = substitution parameter of the lower skill 35-55 years age category, $\mathrm{L}_{155+}{ }^{\mathrm{pl}}=$ substitution parameter of the lower skill 55 years and older age category, $\mathrm{L}_{\mathrm{h} 35 \kappa^{\mathrm{ph}}}=$ substitution parameter for the higher skill 35 years and younger age category and $\mathrm{L}_{555+}{ }^{\mathrm{ph}}=$ substitution parameter for the higher skill 55 years and older age category.

The model also allowed for the computation of the total share of the different age-skill categories in terms of the total employee remuneration costs. These computations gave a clear indication of the relative employee remunerationlabour productivity levels per age-skill category.

\section{Statistical analysis}

The Gauteng Province of South Africa was identified as a case study for this particular study because of the dominant gross geographical product (GGP) position of this particular province in the South African economy. The manufacturing, construction and the trade and accommodation industries in Gauteng were identified as proxy industries based on, (1) the important contribution of these industries to the GGP of Gauteng and (2) the availability of applicable real data.

Information on firms in the manufacturing, construction and the trade and accommodation industries was supplied by Construction Education and Training Authorities (CETA), Manufacturing Sector Education and Traing Authority (CATHSSETA), Service Sector Education and Training Authorities (SERVICES SETA), Manufacturing, Engineering and related service Sector Education and Training Authority (MERSET), Wholesale and Retail Sector Education Authority (W\&RSETA), Food and Beverages Sector Education and Training Authority (FoodBevSETA), the Department of Labour, and Statistics South Africa (StastSA). It was also the aim of the data collection process to make sure that the spread of firms throughout the different industries was statistically significant. In the manufacturing and construction industries, only firms that have more than 80 employees were included in the sample groups. For the trade and accommodation industry, only firms that had more than 10 employees were included. Given the aforementioned constraint and statistical validation requirements, the sample response sizes (192 firms in the manufacturing industry, 96 firms in the construction industry and 89 firms in the trade and accommodation industry) were found to be statistically significant.

For each of the individual firms in the sample groups, data had to be collected on value added, value of the capital stock (including material stock), the hours worked per age group, the hours worked per age-skill category and the hourly earnings by age and by age-skill category. Monthly employee remuneration levels were transformed to hourly rates. Data on the different variables had to be standardised (values were divided by 100000 and logarithms were then computed), in order to enable comparison and application of the data in the estimation process. The summary sample statistics are presented in Appendix A.

The data revealed interesting statistics for the different sample categories. Firstly, the individual percentage contribution of the different age groups to the total hours worked was relatively the same for all three industries. The 35-55 years age group was the biggest contributor (on average 45\%), followed by the 35 years and younger age group (on average $33 \%$ ) and, lastly, the 55 years and older age group (on average $21 \%$ ). Secondly, in terms of the age-skill categories, the lower-skilled category contributed approximately $67 \%$ of the total hours worked (albeit a smaller contribution of $58 \%$ in the trade and accommodation industries), compared to the approximately $33 \%$ contribution of the higher-skilled category (except for the trade and accommodation industries where the contribution was higher at $42 \%$ ). In the lowerskilled segment, the 35-55 years age group was the biggest contributor to the total hours worked, followed by the 35 years and younger age group. In the higher-skilled segment, the spread of the total number of hours worked per age group was more evenly in the case of the manufacturing and construction industries. In the trade and accommodation industry the contribution of the 35-55 years age group was much higher (47\%). Thirdly, for both the lower-skilled and higher-skilled segments, the 35-55 years age groups had, by far, the greatest total employee remuneration capacity (in excess of $60 \%$ ), whilst the total employee remuneration capacity of the 55 years and older age group exceeded that of the 35 years and younger age group.

TABLE 1: Estimation results for the distribution and substitution parameters when the labour input is differentiated by age and skill level.

\begin{tabular}{|c|c|c|c|}
\hline \multirow[t]{2}{*}{ Parameter } & \multicolumn{3}{|c|}{ Parameter estimates } \\
\hline & M & $\mathrm{C}$ & T \& A \\
\hline$\alpha$ & $\begin{array}{c}0.257 \\
(0.0021)\end{array}$ & $\begin{array}{c}0.197 \\
(0.0057)\end{array}$ & $\begin{array}{r}0.204 \\
(0.0087\end{array}$ \\
\hline$\beta$ & $\begin{array}{c}0.691 \\
(0.0068)\end{array}$ & $\begin{array}{c}0.612 \\
(0.0104)\end{array}$ & $\begin{array}{r}0.649 \\
(0.0099\end{array}$ \\
\hline$\delta_{\text {L35< }}$ & $\begin{array}{c}0.418 \\
(0.0450)\end{array}$ & $\begin{array}{c}0.387 \\
(0.0084)\end{array}$ & $\begin{array}{r}0.402 \\
(0.0097\end{array}$ \\
\hline$\delta_{\llcorner 35-55}$ & $\begin{array}{c}0.466 \\
(0.0062)\end{array}$ & $\begin{array}{c}0.471 \\
(0.0101)\end{array}$ & $\begin{array}{r}0.473 \\
(0.0072\end{array}$ \\
\hline$\delta_{\mathrm{t} 55+}$ & 0.116 & 0.142 & 0.125 \\
\hline$\delta_{\text {н35< }}$ & $\begin{array}{c}0.276 \\
(0.0098)\end{array}$ & $\begin{array}{c}0.224 \\
(0.0087)\end{array}$ & $\begin{array}{r}0.249 \\
(0.0170\end{array}$ \\
\hline$\delta_{\text {н35-55 }}$ & $\begin{array}{c}0.376 \\
(0.0176)\end{array}$ & $\begin{array}{c}0.399 \\
(0.0190)\end{array}$ & $\begin{array}{r}0.407 \\
(0.0091\end{array}$ \\
\hline$\delta_{\mathrm{H} 55+}$ & 0.348 & 0.377 & 0.344 \\
\hline$\rho_{\mathrm{L}}$ & $\begin{array}{c}0.503 \\
(0.0087)\end{array}$ & $\begin{array}{c}0.699 \\
(0.0089)\end{array}$ & $\begin{array}{r}0.715 \\
(0.0860\end{array}$ \\
\hline$\rho_{\mathrm{H}}$ & $\begin{array}{c}0.681 \\
(0.0320)\end{array}$ & $\begin{array}{c}0.811 \\
(0.0130)\end{array}$ & $\begin{array}{r}0.726 \\
(0.0093\end{array}$ \\
\hline$\gamma$ & $\begin{array}{c}0.301 \\
(0.0088)\end{array}$ & $\begin{array}{c}0.386 \\
(0.0160)\end{array}$ & $\begin{array}{r}0.293 \\
(0.0097\end{array}$ \\
\hline $1-\gamma$ & 0.699 & 0.614 & 0.707 \\
\hline
\end{tabular}

$\alpha$, marginal productivity of capital; $\beta$, marginal productivity of labour; $\delta_{235<}$, distribution parameter for the less skilled category of employees younger than 35 years of age; $\delta$ L35-55, distribution parameter for the less skilled category of employees for the 35-55 age group; $\delta_{155}$, distribution parameter for the less skilled category of employees older than 55 years of age; $\delta_{H 35<}$, distribution parameter for the higher skilled category of employees younger than 35 years of age; $\delta$ H35.55, distribution parameter for the higher skilled category of employees for the 35-55 age group; $\delta_{H 55+}$, distribution parameter for the higher skilled of employees for the 35-55 age group; $\mathrm{DH}_{55+}$, distribution parameter for the higher skilled category of employees older than 55 years of age; $\rho_{l^{\prime}}$ substitution parameter for the lowe

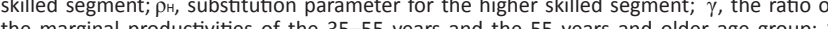
the marginal productivities of the 35-55 years and the 55 years and older age group; $-\gamma$, residual of the marginal productivities ratio of the $35-55$ years and the 55 years and older age group; $\mathrm{M}$, manufacturing industry; $\mathrm{C}$, construction industry; $\mathrm{T} \& \mathrm{~A}$, trade and accommodation industry.

The standard errors are significant at a $10 \%$ confidence level and are in parenthesis. 


\section{Results}

The parameter estimates of the non-linear production functions are listed in Table 1 . The estimations in Table 1 were used to compute, (1) the marginal productivity contribution of each age-skill category and (2) a remunerationproductivity profile for the different age-skill categories (Equations 4-16). This was conducted for each firm in the sample groups. In order to perform a general comparison of all the productivity contributions of the different ageskill categories, (1) a marginal productivity contribution mean value was computed for each of the three industries and (2) the ratio of marginal productivity contribution was computed for each age-skill category for the individual firms and the industry marginal productivity contribution mean value. Average ratios for each age-skill category per industry were then computed. If the ratio of the marginal productivity contribution of a specific age-skill category and the mean marginal productivity contribution value equalled 1 , the marginal productivity contribution of that specific age-skill category was the same as the industry average. If the value of the ratio was greater than 1 the marginal productivity contribution of that particular age-skill category exceeded the industry average, and if the ratio was less than 1 the marginal productivity contribution was less than the industry average. All the computed average marginal productivity contribution ratio values for the different age-skill categories in the different industries are listed in Table 2.

Analysts should not only concern themselves with relative productivity contribution levels but should also consider the applicable employee remuneration cost aspect of a particular productivity contribution level. From a productivity contribution-employee remuneration cost perspective, it was deemed necessary to compute the marginal productivity contribution-marginal employee remuneration cost ratios for each of the age-skill categories in the different industries. This simply meant that the productivity contributions were matched with the employee remuneration costs. If the productivity contribution-employee remuneration cost ratio was greater than 1 , the relative productivity contribution of a particular age-skill category exceeded the relative employee remuneration cost of that age-skill group and if the ratio was smaller than 1 , the relative productivity contribution of a particular age-skill category was less than the relative employee remuneration cost of that age-skill group.

The computation of the marginal productivity-employee remuneration ratios also required the computation of the marginal employee remuneration cost ratios (i.e. average employee remuneration cost per age-skill category divided by average employee remuneration cost for the industry). If the relative employee remuneration cost ratio was greater than 1, the average employee remuneration cost of that particular age-skill category exceeded the average employee remuneration cost of the employers and if the ratio was less than 1 , the average employee remuneration
TABLE 2: Marginal productivity ratios per age-skill category for the three industries.

\begin{tabular}{|c|c|c|c|c|}
\hline \multirow[t]{2}{*}{ Skill category } & \multirow[t]{2}{*}{ Age-skill category } & \multicolumn{3}{|c|}{ Industry } \\
\hline & & M & C & T \& A \\
\hline \multirow[t]{3}{*}{ Lower-skilled } & Younger than 35 years $\left(L_{35}<\right)$ & $\begin{array}{c}0.82 \\
(0.36)\end{array}$ & $\begin{array}{c}0.71 \\
(0.28)\end{array}$ & $\begin{array}{c}0.92 \\
(0.26)\end{array}$ \\
\hline & $35-55$ years $\left(L_{35-55}\right)$ & $\begin{array}{l}1.07 \\
(0.12)\end{array}$ & $\begin{array}{c}1.01 \\
(0.08)\end{array}$ & $\begin{array}{c}1.02 \\
(0.10)\end{array}$ \\
\hline & 55 years and older $\left(L_{55+}\right)$ & $\begin{array}{c}0.86 \\
(0.04)\end{array}$ & $\begin{array}{c}0.61 \\
(0.06)\end{array}$ & $\begin{array}{c}0.81 \\
(0.02)\end{array}$ \\
\hline \multirow[t]{3}{*}{ Higher-skilled } & Younger than 35 years $\left(\mathrm{L}_{35<}\right)$ & $\begin{array}{c}0.95 \\
(0.18)\end{array}$ & $\begin{array}{c}0.86 \\
(0.15)\end{array}$ & $\begin{array}{c}1.02 \\
(0.16)\end{array}$ \\
\hline & $35-55$ years $\left(\mathrm{L}_{35-55}\right)$ & $\begin{array}{c}1.09 \\
(0.08)\end{array}$ & $\begin{array}{l}1.08 \\
(0.11)\end{array}$ & $\begin{array}{c}1.04 \\
(0.10)\end{array}$ \\
\hline & 55 years and older $\left(L_{55+}\right)$ & $\begin{array}{c}1.24 \\
(0.12)\end{array}$ & $\begin{array}{l}1.17 \\
(0.06)\end{array}$ & $\begin{array}{c}1.14 \\
(0.09)\end{array}$ \\
\hline
\end{tabular}

$\mathrm{M}$, manufacturing; $\mathrm{C}$, construction; $\mathrm{T} \& \mathrm{~A}$, trade and accommodation. The mean absolute deviations are in parenthesis.

of that particular age-skill category was smaller than the average employee remuneration costs of the employers. The employee remuneration and the productivity contributionemployee remuneration cost ratios of all the different ageskill categories for the three industries are listed in Table 3.

\section{Discussion}

The aim of the article was to estimate, compute, quantify and interpret the real productivity levels for the different employee age groups when different skill levels are taken into consideration.

The estimation results of the marginal ratios per age-skill category indicated that for the lower-skilled category, the 55 years and older age group had the lowest productivity contribution whilst the 35-55 years age group had the highest productivity contribution (the relative productivity contribution levels of this particular age group marginally exceeded the average industry productivity contribution levels for the three industries). It was also significant to note that for the 35 years and younger age group the productivity contribution was less than the average industry productivity contribution levels. These results are a confirmation of the general perception of low productivity levels for the lowerskilled employee component of the South African economy. The challenge for human resource practitioners (given the perceived rigidity of current labour legislation) is to (1) enhance a greater understanding of the importance of higher productivity levels in the workplace and (2) implement structures that would promote and monitor productivity levels more efficiently and to constantly improve work-based training.

The abovementioned findings are in contrast with the findings of the Roger and Wasmer (2009) study, which indicated a significant productivity contribution (exceeding the average industry productivity contribution) of the 'younger' age group (in those particular developed economies).

The results derived for the higher-skilled segment are in contrast with the results derived for the lower-skilled segment. The 55 years and older age group generated relative productivity contributions that significantly exceeded the 
TABLE 3: Employee remuneration and the productivity contribution-employee remuneration ratios per age-skill category for the three industries.

\begin{tabular}{|c|c|c|c|c|c|c|c|}
\hline \multirow[t]{3}{*}{ Skill category } & \multirow[t]{3}{*}{ Age-skill category } & \multicolumn{6}{|c|}{ Industry } \\
\hline & & \multicolumn{2}{|c|}{$M$} & \multicolumn{2}{|c|}{ C } & \multicolumn{2}{|c|}{$T \& A$} \\
\hline & & $\mathbf{R}$ & P-R & $\mathbf{R}$ & P-R & $\mathbf{R}$ & $\mathbf{P}-\mathbf{R}$ \\
\hline \multirow[t]{3}{*}{ Lower-skilled } & Younger than 35 years $\left(\mathrm{L}_{35<}\right)$ & $\begin{array}{c}0.98 \\
(0.11)\end{array}$ & $\begin{array}{c}0.83 \\
(0.08)\end{array}$ & $\begin{array}{c}0.91 \\
(0.13)\end{array}$ & $\begin{array}{c}0.78 \\
(0.09)\end{array}$ & $\begin{array}{c}0.99 \\
(0.09)\end{array}$ & $\begin{array}{c}0.92 \\
(0.15)\end{array}$ \\
\hline & $35-55$ years $\left(\mathrm{L}_{35-55}\right)$ & $\begin{array}{c}1.03 \\
(0.09)\end{array}$ & $\begin{array}{c}1.04 \\
(0.11)\end{array}$ & $\begin{array}{c}0.99 \\
(0.10)\end{array}$ & $\begin{array}{c}1.02 \\
(0.11)\end{array}$ & $\begin{array}{c}0.98 \\
(0.11)\end{array}$ & $\begin{array}{c}1.04 \\
(0.16)\end{array}$ \\
\hline & 55 years and older $\left(\mathrm{L}_{55+}\right)$ & $\begin{array}{c}1.09 \\
(0.07)\end{array}$ & $\begin{array}{c}0.78 \\
(0.09)\end{array}$ & $\begin{array}{c}1.14 \\
(0.03)\end{array}$ & $\begin{array}{c}0.54 \\
(0.07)\end{array}$ & $\begin{array}{l}1.07 \\
(0.03)\end{array}$ & $\begin{array}{c}0.76 \\
(0.09)\end{array}$ \\
\hline \multirow[t]{3}{*}{ Higher-skilled } & Younger than 35 years $\left(\mathrm{L}_{35<}\right)$ & $\begin{array}{c}0.97 \\
(0.11)\end{array}$ & $\begin{array}{c}0.98 \\
(0.13)\end{array}$ & $\begin{array}{c}0.83 \\
(0.06)\end{array}$ & $\begin{array}{c}0.96 \\
(0.12)\end{array}$ & $\begin{array}{c}0.98 \\
(0.03)\end{array}$ & $\begin{array}{c}1.04 \\
(0.08)\end{array}$ \\
\hline & $35-55$ years $\left(L_{35-55}\right)$ & $\begin{array}{c}0.99 \\
(0.04)\end{array}$ & $\begin{array}{l}1.10 \\
(0.06)\end{array}$ & $\begin{array}{c}0.99 \\
(0.12)\end{array}$ & $\begin{array}{l}1.09 \\
(0.14)\end{array}$ & $\begin{array}{l}1.01 \\
(0.12)\end{array}$ & $\begin{array}{l}1.03 \\
(0.11)\end{array}$ \\
\hline & 55 years and older $\left(\mathrm{L}_{55+}\right)$ & $\begin{array}{c}1.11 \\
(0.13)\end{array}$ & $\begin{array}{c}1.12 \\
(0.14)\end{array}$ & $\begin{array}{c}1.03 \\
(0.09)\end{array}$ & $\begin{array}{l}1.13 \\
(0.07)\end{array}$ & $\begin{array}{l}1.09 \\
(0.03)\end{array}$ & $\begin{array}{c}1.05 \\
(0.12)\end{array}$ \\
\hline
\end{tabular}

$\mathrm{M}$, manufacturing; $\mathrm{C}$, construction; $\mathrm{T} \& \mathrm{~A}$, trade and accommodation; $\mathrm{R}$, employee remuneration ratios; $\mathrm{P}-\mathrm{R}$, productivity-employee remuneration ratios.

The mean absolute deviations are in parenthesis.

average industry productivity levels. The same applies to the 35-55 years age group, but at a relative smaller magnitude. These results are similar to the findings of the ColoniaWillner (1998) and Roger and Wasmer (2009) studies, which indicated high productivity levels for the 'older' age group in the higher-skilled segment. A plausible explanation is that for certain higher-skilled occupations, a high level of longer job experience and 'learning by doing' effects are a necessity. Given the significant higher productivity contribution levels of the higher-skilled segment (in comparison with the lower-skilled segment) it is important that, (1) older highlyskilled employees are kept in the workplace for as long as possible and (2) that structures are put in place that could limit any outflow of high-skilled employees from the South African workplace. It is surprising to note that the relative productivity contribution of the 35 years and younger age group still remained lower than the average industry productivity contribution levels (albeit better than the lowerskilled segment). In this regard, it is felt that the productivity levels of this particular age-skill category can be improved by enhancing the quality and speed of learning and training and to rigorously keep track with technological progress.

In terms of the productivity contribution-employee remuneration cost component the results of the study should be of great interest to human resource and remuneration specialists. In the case of the lower-skilled segment the productivity contribution-employee remuneration cost ratio for both the younger than 35 years and older than 55 years age groups were smaller than 1 (for all three industries). This is a clear indication that relative productivity contributions are lower than relative employee remuneration costs. In simplistic terms, it reflects a situation where both age groups are paid more than they should be paid when productivity levels are considered. The productivity contribution-employee remuneration levels are especially low for the older than 55 years age group. This particular outcome was also recorded in the Remery et al. (2003) and the Rogers and Wasmer (2009) studies. In the case of the 35-55 years age group, the productivity contribution-employee remuneration cost ratios were marginally higher than 1 (for all three industries), thus indicating a situation where the relative productivity contributions matched the relative employee remuneration costs. The abovementioned discussion is again a confirmation of the general perception that the relative remuneration costs of lower-skilled employees in South Africa is too high. Given the unionised nature of this particular skill segment, the challenge for human resource practitioners (as mentioned earlier) is to implement effective strategies that would enhance higher productivity levels (especially for an everexpanding younger than 35 years age group in the South African labour market).

The situation is totally reversed when the higher-skilled segment is considered. The productivity contributionemployee remuneration cost ratios of the 55 years and older age group (greater than 1) was greater than the other two age groups (in all three industries). This is a clear confirmation of the superior productivity contribution levels of this particular age-skill group. These results have been obtained even when the relative employee remuneration cost ratios were greater than 1 (for all three industries), which simply means that the relative productivity contributions of this particular age group exceeded the relative high employee remuneration costs. The productivity contribution-employee remuneration cost ratio for the 35-55 years age group was also greater than 1 (indicating high levels of relative productivity contributions). The younger than 35 years age group also presented better relative productivity contribution-employee remuneration cost ratios (compared to the lower-skilled segment). These ratios were slightly less than 1 , indicating a situation where relative productivity contributions nearly match relative employee remuneration costs.

\section{Conclusion}

The results of this particular study are, again, a confirmation of, (1) relative low productivity levels and relative high employee remuneration costs in the more unionised lowerskilled segment of the South African labour market, (2) the absolute need to improve the productive skill base of the labour market and (3) the need to maintain skilled employees (for all age groups) in the workplace. Further possible extensions of this particular study are, (1) the relative productivity contribution levels of the two gender groups (for the three age-skill categories) and (2) geographical 
differences in terms of relative productivity contribution levels (for the three age-skill categories).

\section{Acknowledgements \\ Competing interests}

The author declares that he has no financial or personal relationships which may have inappropriately influenced him in writing this article.

\section{References}

Colonia-Willner, R. (1998). Practical intelligence at work: Relationship between aging and cognitive efficiency among managers in a bank environment. Psychology and Aging, 13(1), 1-57. http://dx.doi.org/10.1037/0882-7974.13.1.45, PMid:9533189

Daveri, F., \& Maliranta, M. (2006). Age, technology and labour costs. Research Institute of the Finish Economy Paper Series, (1010), 1-51.
Dostie, B. (2006). Wages, productivity and aging. International Zeolite Association Discussion Paper Series, (2496), 1-32.

Guest, R., \& Shacklock, K. (2005). The impending shift to an older mix of workers: Perspectives from the management and economics literatures. Journal of Organisational Behaviour, 10(3), 713-728.

Malmberg, B., Lindh, T., \& Halvarsson, M. (2005). Productivity consequences of workforce ageing. Arbetsrapport, 17, 1-43.

Remery, C., Henkens, K., Schippers, J., \& Ekamper, P. (2003). Managing an ageing workforce and a tight labour market. Population Research and Policy Review, 22(1), 21-40. http://dx.doi.org/10.1023/A:1023543307473

Roger, M., \& Wasmer, M. (2009). Heterogeneity matters: Labour productivity differentiated by age and skills. National Institute of Statistics and Economic Studies, (4), 1-37.

Skirbekk, V. (2003). Age and individual productivity: A literature survey. Max Planck Institute for Demographic Research Working Paper Series, (028), 1-37.

Vandenberghe, V., \& Waltenberg, F. (2010). Ageing workforce, productivity and labour costs of Belgium firms. Institut de Recherches Economiques et Sociales Paper Series, (3), 1-30.

Van Ours, J.C., \& Stoeldraijer, L. (2010). Age, wage and productivity. International Zeolite Association Discussion Paper Series, (4765), 1-50. 


\section{Appendix A}

APPENDIX A: Summary of the sample statistics.

\begin{tabular}{|c|c|c|c|c|c|c|c|}
\hline \multirow[t]{2}{*}{ Category } & \multirow[t]{2}{*}{ Variables } & \multicolumn{2}{|c|}{ M } & \multicolumn{2}{|c|}{ C } & \multicolumn{2}{|c|}{$T \& A$} \\
\hline & & Share & Mean & Share & Mean & Share & Mean \\
\hline & $L n$ value added & - & $\begin{array}{l}-3.56 \\
(0.99)\end{array}$ & - & $\begin{array}{l}-2.79 \\
(0.76)\end{array}$ & - & $\begin{array}{l}-3.08 \\
(1.01)\end{array}$ \\
\hline & Ln capital stock & - & $\begin{array}{l}-3.89 \\
(1.04)\end{array}$ & - & $\begin{array}{l}-3.06 \\
(0.92)\end{array}$ & - & $\begin{array}{l}-3.67 \\
(1.12)\end{array}$ \\
\hline \multirow[t]{4}{*}{ Hours worked per age category } & Total & 1.00 & $\begin{array}{c}4.93 \\
(0.83)\end{array}$ & 1.00 & $\begin{array}{c}4.68 \\
(1.07)\end{array}$ & 1.00 & $\begin{array}{r}4.30 \\
(1.11)\end{array}$ \\
\hline & Younger than 35 years $\left(\mathrm{L}_{35}<\right)$ & 0.33 & $\begin{array}{c}1.64 \\
(0.54)\end{array}$ & 0.33 & $\begin{array}{c}1.56 \\
(1.02)\end{array}$ & 0.33 & $\begin{array}{c}1.44 \\
(0.87)\end{array}$ \\
\hline & $35-55$ years $\left(\mathrm{L}_{35-55}\right)$ & 0.48 & $\begin{array}{c}2.37 \\
(1.01)\end{array}$ & 0.45 & $\begin{array}{r}2.09 \\
(0.99)\end{array}$ & 0.46 & $\begin{array}{c}1.97 \\
(1.02)\end{array}$ \\
\hline & 55 years and older $\left(L_{55+}\right)$ & 0.19 & $\begin{array}{c}0.92 \\
(0.24)\end{array}$ & 0.22 & $\begin{array}{l}1.03 \\
(0.47)\end{array}$ & 0.21 & $\begin{array}{c}0.89 \\
(0.38)\end{array}$ \\
\hline \multirow[t]{7}{*}{ Hours worked per age-skill category } & Lower-skilled (LI) & 0.67 & $\begin{array}{c}3.30 \\
(1.23)\end{array}$ & 0.67 & $\begin{array}{l}3.12 \\
(1.01)\end{array}$ & 0.58 & $\begin{array}{r}2.50 \\
(1.02)\end{array}$ \\
\hline & Younger than 35 years (Lly) & 0.32 & $\begin{array}{c}1.04 \\
(0.77)\end{array}$ & 0.31 & $\begin{array}{c}0.98 \\
(0.56)\end{array}$ & 0.36 & $\begin{array}{l}0.89 \\
(0.43)\end{array}$ \\
\hline & 55 years and older (Llo) & 0.15 & $\begin{array}{c}0.51 \\
(0.11)\end{array}$ & 0.21 & $\begin{array}{l}0.65 \\
(0.25)\end{array}$ & 0.19 & $\begin{array}{l}0.49 \\
(0.24)\end{array}$ \\
\hline & Higher-skilled (Lh) & 0.33 & $\begin{array}{c}1.63 \\
(0.91)\end{array}$ & 0.33 & $\begin{array}{l}1.56 \\
(0.88)\end{array}$ & 0.42 & $\begin{array}{r}1.80 \\
(1.15)\end{array}$ \\
\hline & Younger than 35 years (Lhy) & 0.37 & $\begin{array}{l}0.60 \\
(0.29)\end{array}$ & 0.37 & $\begin{array}{l}0.58 \\
(0.12)\end{array}$ & 0.31 & $\begin{array}{c}0.55 \\
(0.21)\end{array}$ \\
\hline & $35-55$ years $(\mathrm{Lhm})$ & 0.38 & $\begin{array}{c}0.62 \\
(0.45)\end{array}$ & 0.38 & $\begin{array}{l}0.60 \\
(0.11)\end{array}$ & 0.47 & $\begin{array}{c}0.85 \\
(0.37)\end{array}$ \\
\hline & 55 years and older (Lho) & 0.25 & $\begin{array}{c}0.41 \\
(0.22)\end{array}$ & 0.25 & $\begin{array}{l}0.38 \\
(0.14)\end{array}$ & 0.22 & $\begin{array}{l}0.40 \\
(0.17)\end{array}$ \\
\hline \multirow[t]{6}{*}{$\begin{array}{l}\text { Hourly remuneration per age-skill } \\
\text { category }\end{array}$} & Lower-skilled (니) & 0.42 & $\begin{array}{r}41.56 \\
(11.75)\end{array}$ & 0.41 & $\begin{array}{c}39.24 \\
(16.13)\end{array}$ & 0.38 & $\begin{array}{l}31.29 \\
(11.98)\end{array}$ \\
\hline & Younger than 35 years (Lly) & 0.21 & $\begin{array}{l}35.12 \\
(9.75)\end{array}$ & 0.23 & $\begin{array}{c}33.78 \\
(14.28)\end{array}$ & 0.26 & $\begin{array}{r}29.29 \\
(10.58)\end{array}$ \\
\hline & $35-55$ years (LIm) & 0.60 & $\begin{array}{c}42.78 \\
(10.08)\end{array}$ & 0.63 & $\begin{array}{l}40.99 \\
(9.48)\end{array}$ & 0.59 & $\begin{array}{l}38.98 \\
(9.98)\end{array}$ \\
\hline & Younger than 35 years (Lhy) & 0.17 & $\begin{array}{l}42.08 \\
(11.65)\end{array}$ & 0.15 & $\begin{array}{c}41.12 \\
(10.03)\end{array}$ & 0.14 & $\begin{array}{l}34.06 \\
(8.66)\end{array}$ \\
\hline & $35-55$ years $(\mathrm{Lhm})$ & 0.61 & $\begin{array}{l}59.12 \\
(13.76)\end{array}$ & 0.64 & $\begin{array}{l}58.09 \\
(12.73)\end{array}$ & 0.67 & $\begin{array}{l}48.11 \\
(10.42)\end{array}$ \\
\hline & 55 years and older (Lho) & 0.22 & $\begin{array}{l}61.87 \\
(15.62)\end{array}$ & 0.21 & $\begin{array}{c}60.34 \\
(11.86) \\
\end{array}$ & 0.19 & $\begin{array}{r}49.89 \\
(9.38) \\
\end{array}$ \\
\hline Total observations & & - & 192.00 & - & 96.00 & - & 89.00 \\
\hline
\end{tabular}

$L n$, linear-log value; $M$, manufacturing industry; $C$, construction industry; $T \& A$, trade and accommodation industry. The standard deviations are in parenthesis. 